training future physiotherapists in higher education institutions in Ukraine and the need to update curriculum, information and scientific-methodological provision of this process.

Key words training, physical therapist, Danish universities, bachelor, curriculum.

удк 37-047(410)

Валентина Швиденко

Перша міська гімназія, м. Черкаси ORCID ID 0000-0002-3207-4384

DOI 10.24139/2312-5993/2020.09/458-468

\title{
СТАН ОПРАЦЮВАННЯ ПРОБЛЕМИ ОРГАНІЗАЦІЇ ВИХОВНОЇ РОБОТИ В ЗАКЛАДАХ СЕРЕДНЬОЇ ОСВІТИ ВЕЛИКОЇ БРИТАНІЇ У СУЧАСНОМУ НАУКОВОМУ ДИСКУРСІ
}

У статті розкрита проблема організачії виховної роботи в закладах середньої освіти Великої Британії у працях вітчизняних на зарубіжних науковців. Висвітлено різні погляди педагогів на виховання в закладах середньої освіти Великої Британії, основна увага яких зосереджується на вихованні моральних якостей дітей, організації сімейного виховання дітей у Великій Британії. у статті показано роль сучасної британської сім'ї у вихованні дітей. Зазначено, що інтегративною складовою $\epsilon$ орієнтація на виховання особистості з розвиненим естетичним світоглядом, який ґрунтується на загальнолюдських цінностях і пріоритетах. Відображено патріотичне виховання, що сприяє критичному діалогу $i$ демократичного процесу, здатне об'єднати людей у всьому різноманітті багатонаціонального суспільства. Продемонстровано гендерне виховання учнів закладів середньої освіти у Великій Британії.

Ключові слова: виховна робота, заклади середньої освіти, Велика Британія, dimu, освіта.

Постановка проблеми. У ситуації глобалізації, розширення міграційних процесів, загострення соціальних проблем дитинства на виховання звертається увага як на актуальний напрямок діяльності шкільних освітніх організацій. У центрі уваги виявляється досвід, підходи і принципи виховної роботи з учнями. Виховання дітей - важлива тема наукових дискусій в англійській педагогіці, оскільки воно є невід'ємною складовою складного процесу формування особистості. В їі обговоренні активну участь беруть педагоги Великої Британії.

У Великій Британії проблему виховання введено в ранг державної політики країни і воно належить до невід'ємних компонентів освітньої системи школи; здійснюється в єдності зі світоглядним, розумовим, моральним, естетичним, фізичним і трудовим вихованням школярів та виступає необхідною складовою всебічного розвитку індивіда, про що свідчить аналіз праць, які стосуються виховної роботи британської системи освіти.

Аналіз актуальних досліджень. У межах наукового дискурсу запропоновано праці відомих українських дослідників У межах нашого 
дослідження було схарактеризовано праці вітчизняних науковців, які зробили значний внесок у дослідження сучасних освітньо-виховних систем Великої Британії (Н. Величко, Т. Кравченко, М. Лещенко, О. Локшина, Л. Лушпай, Н. Мороз, А. Сбруєва, Г. Теклюк, С. Червонецька, В. Червонецький та ін.), а також до аналізу залучено праці британських дослідників із проблеми організації виховної роботи в закладах середньої освіти Великої Британії (С. Бердан (S. Berdan), А. Беррі (A. Berry), С. Блендфорд (S. Blandford), E. Вейн (E.Wayne), М. Волкер (M. Walker). Д. Геррет (D. Garratt), C. Джексон (S. Jackson), К. Камерон (C. Cameron), К. Картер (C. Carter), Г. Конеллі (G. Connelly), C. Маршал (S.Marshall), M. Мейсон (M. Mason), К. Ноулз (C. Knowles), Р. Огустроп (R. Ogusthrope), M. Петерсон Фенн (M. Peterson Fenn), Х. Піпер (H. Piper), Т. Расел (T. Russell), M. Сенгер (M. Sanger), М. Тейлор (M. Taylor) та ін.).

Метою статті є опрацювання проблеми організації виховної роботи в закладах середньої освіти Великої Британії у працях вітчизняних на зарубіжних науковців. Відповідно до мети визначено такі завдання статті: здійснити аналіз наукових доробків учених щодо проблеми організації виховної роботи в закладах середньої освіти Великої Британії.

Методи дослідження. Для досягнення поставленої мети використано такі методи дослідження: теоретичні (аналіз філософської, педагогічної, психологічної літератури), що дає змогу обґрунтувати вихідні положення дослідження; інтерпретаційно-аналітичний метод, на основі якого вивчаються джерела із застосуванням синтезу, аналізу, систематизації та узагальнення.

Виклад основного матеріалу. Ураховуючи той факт, що британці мають вагомі здобутки в сімейній педагогіці, де питання морального виховання посідають чільне місце, виникає потреба в їхньому різносторонньому висвітленні з метою конструктивного використання в українській сімейній педагогіці. Оскільки Україна як незалежна європейська держава є активним суб'єктом міжнародного співробітництва, важливою складовою якого $€$ освіта (яскравим підтвердженням цього слугує підписання Болонської декларації і участь у Болонському процесі), то вивчення і творче застосування досвіду виховання людини з високими моральними якостями в сім'ї в одній із провідних країн європейського регіону і світу - Великій Британії, з урахуванням традицій сімейного виховання в Україні, є надзвичайно актуальним.

Наукове зацікавлення викликають праці В.Червонецького та С. Червонецької, основна увага яких зосереджується на вихованні 
моральних якостей дітей молодшого шкільного віку в сучасній британській сім'ї. Звертання до цієї вікової категорії дітей обумовлене науковим інтересом, пов'язаним із вивченням і узагальненням досвіду в даній галузі виховної діяльності сім'ї. Також, науковці наголошують на актуальній педагогічній проблемі сьогодення - вивченню і узагальненню досвіду виховання моральних якостей дітей шкільного віку в сім'ї на прикладі Великої Британії. у їх роботах знаходить фундаментальне висвітлення застосування різноманітних форм педагогічної просвіти батьків, яка перманентно розвивається за підтримки уряду країни, досвід конструктивної співпраці батьків і педагогів у вихованні моральних якостей дітей засобами природи; використання в сімейному вихованні України найбільш перспективні форми, методи й засоби формування етикоморальних якостей дітей шкільного віку, що позитивно зарекомендували себе у Великій Британії (Червонецький та Червонецька, 2010).

Продовжуючи думку щодо проблеми сімейного виховання у Великій Британії, Г. Теклюк у своїй дисертаційній роботі «Проблеми сімейного виховання дітей підліткового віку у Великій Британії» з'ясовує тенденції розвитку та здійснює аналіз концепцій організації сімейного виховання дітей підліткового віку Великої Британії, висвітлює роль сучасної британської сім'ї у вихованні дітей у неблагополучних сім'ях, визначає зміст сімейного виховання дітей Великої Британії, досліджує форми та методи сімейного виховання британців, також авторкою здійснено компаративний аналіз української і британської систем сімейного виховання дітей підліткового віку (Теклюк, 2013).

Вивчаючи теоретичні основи естетичного виховання в зарубіжних країнах, у тому числі й у Великій Британії, М. Лещенко зазначає, що інтегративною складовою цих теорій є орієнтація на виховання особистості з розвиненим естетичним світоглядом, який ґрунтується на загальнолюдських цінностях і пріоритетах. Вона наголошує, що відродження української національної школи забезпечує естетизація всіх ланок навчально-виховного процесу, створення теоретичних засад естетичного виховання особистості (Лещенко, 1996).

Торкаючись проблеми естетичного виховання учнів британських шкіл, Н. Величко присвячує свої доробки естетичному вихованню учнів початкових класів у школах Великої Британії. На основі аналізу численних джерел, науково-педагогічної літератури, нормативних документів британського та українського урядів, програм навчання і виховання в сучасній парадигмі освіти авторкою визначено, схарактеризовано й науково обґрунтовано 
структуру, зміст, завдання, форми та методи організації естетико-виховної системи Великої Британії, з'ясовано сучасні підходи до естетичного виховання в закладах початкової освіти Великої Британії; проаналізовано напрями естетичного виховання учнів у закладах початкової освіти Великої Британії; визначено подібне й відмінне в підходах як британських, так і вітчизняних науковців до визначення поняття «естетичне виховання». Теоретично обґрунтовані педагогічні умови формування естетичної свідомості учнів естетичними засобами; узагальнено досвід їх організації й показано взаємозв'язок школи, сім'ї та громадськості в процесі естетичного виховання; проаналізовано практичну спрямованість засобів, форм і методів естетичного виховання і визначено значення міжпредметних зв'язків у процесі естетичного виховання. У працях також проаналізовано зміст естетичного виховання учнів британських шкіл на заняттях академічного циклу, а також у позакласній роботі. Виявлено можливості застосування раціональних ідей естетичного виховання учнів закладів початкової освіти Великої Британії в школах України (Величко, 2015).

О. Локшина, здійснюючи наукові дослідження з питань порівняльної педагогіки, розглядаючи теоретичні питання культури, освіти та виховання, реформування шкільної освіти, структурування змісту освіти в країнах ЄС та США, оцінювання навчальних досягнень учнів в Україні та за кордоном, здійснюючи аналіз освітньої політики виховання у країнах Європи, ставить наголос на проблемах теорії і практики добору та структурування змісту шкільної освіти в країнах Європейського Союзу на тлі соціальних, економічних і педагогічних трансформацій другої половини XX - початку XXI століття (Локшина, 2009).

Систему виховної роботи в закладах середньої освіти Великої Британії досліджує Н. Мороз. На основі аналізу численних джерел нею реалізовано низку завдань: схарактеризовано та науково обґрунтовано структуру й організацію освітньо-виховної системи, з'ясовано сучасні підходи до виховання в закладах середньої освіти Великої Британії, зокрема концепцію пасторальної опіки; проаналізовано напрями виховання учнів у закладах середньої освіти Великої Британії й узагальнено досвід їх організації; з'ясовано роль і функції класного керівника у виховній системі закладів середньої освіти Великої Британії та показано взаємозв'язок школи, сім'ї й громадськості в процесі виховання; виявлено можливості застосування раціональних ідей виховання підростаючого покоління закладів середньої освіти Великої Британії в школах України (Мороз, 2009). 
Варта дослідницької уваги наукова праця Т. Кравченко «Особливості патріотичного виховання у Великій Британії», у якій з'ясовано, що $з$ історичних причин більшість європейських країн використовують ненав'язливий метод розвитку патріотичного виховання молоді. Автор зауважує, що для Великої Британії, як для багатонаціонального суспільства, має важливість конструктивний і демократичний патріотизм. На основі дослідженого матеріалу узагальнено, що патріотичне виховання, яке підкреслює національну гордість і некритичну повагу до влади, дає лише поверхневі прояви єдності - фасад, який насправді може привести до поділу. Навпаки, патріотичне виховання, яке сприяє критичному діалогу й демократичному процесу, здатне об'єднати людей у всьому різноманітті багатонаціонального суспільства. Зроблено висновок, що заклади вищої освіти можуть і повинні відігравати провідну роль у формуванні патріотизму. У роботі підсумовується, що громадянська активність і патріотичне виховання молоді $\epsilon$ найважливішими завданнями інтелектуального стратегічного розвитку країни (Кравченко, 2019).

Імпонують міркування Л. Лушпай, автора праці «Гендерне виховання учнів середніх навчальних закладів у Великій Британії», стосовно змісту й організації ґендерного виховання учнів закладів середньої освіти у Великій Британії. У розвідці окреслено особливості ґендерного виховання учнів у Великій Британії та його основні напрями (створення інформаційноосвітнього середовища на засадах гуманістичної педагогіки та феміністичної теорії, пріоритетність громадянської освіти підлітків із метою формування ґендерної культури в учнівської молоді, упровадження антибулінгових стратегій у навчально-виховний процес, проведення профорієнтаційної роботи серед підлітків із урахуванням ґендерної складової, підвищення ґендерної обізнаності педагогів, партнерська взаємодія школи та виховних інституцій тощо) (Лушпай, 2012).

Ґрунтовний компаративний аналіз тенденцій реформування середньої освіти розвинених англомовних країнах у контексті глобалізації провела А. Сбруєва, аргументувавши психолого-педагогічні та економічні проблеми гуманізації навчально-виховного процесу в закладах освіти, результати якої повинні спрямовуватися на потреби вдосконалення навчально-виховної роботи школи та покращення ії матеріальнотехнічного забезпечення. Дослідницею розкрито особливості політичних механізмів реформ, а саме централізаційно-децентралізаційних процесів, що включали запровадження освітніх стандартів та програм автономного шкільного менеджменту у Великій Британії. Подано характеристику 
реформ професійно-освітньої сфери як невід'ємної складової сучасних реформ середньої освіти. Зроблено висновки щодо суперечностей, недоліків реформ та умов їх ефективного запровадження. Сформульовано рекомендації щодо особливостей використання уроків дослідженого реформаційного досвіду в Україні (Сбруєва, 2005).

В умовах розширеної взаємодії всіх країн неможливо аналізувати розвиток системи вітчизняної педагогічної освіти і виховання поза світовим контекстом динаміки навчального простору, що актуалізує необхідність у всебічному науковому дослідженні змісту та форм організації виховної роботи. Дослідження європейського досвіду, зокрема досвіду Великої Британії, дасть можливість удосконалити розвиток української системи навчання і виховання, а також вирішити конкретні завдання, що постають перед педагогами України. Важливе значення мають порівняльнопедагогічні студії, що сфокусовані на вивченні організації виховної роботи в розвинених країнах, на описі різних освітніх та виховних систем, а також практичного досвіду, що потрібен для запозичення та впровадження в Україні. Аналіз британських джерел засвідчує, що проблему організації виховної роботи, потрактовану в сучасному науковому дискурсі, проаналізовано різними британськими науковцями, які представляють порівняльно-педагогічні системи освіти.

Як слушно зауважує E. Вейн (E. Wayne) у своїй праці «як успішно виховати дітей», що його книга покликана допомогти батькам спрямувати своїх дітей у доросле життя як упевнених та підготовлених людей. Він наголошує у праці про основні теми для батьків, якими сьогодні вони повинні активно займатися зі своїми дітьми, щоб виховувати щасливих, здорових, задоволених життям дітей (Wayne, 2013).

Вивчаючи британські системи виховання, М. Петерсон Фенн (M.Peterson Fenn) зазначає, виховання дітей, може бути важким, складним, часто самотнім і заплутаним. Ї̈̈ праця висвітлює такі питання, як британські системи виховання, культурні цінності, звичаї та традиції, ідентичність та мовні бар'єри, а також розглядає цікаве та цінне розуміння британської культури з різних точок зору (Peterson Fenn, 2011).

Посилаючись на ідеї соціальної педагогіки, автори К. Камерон, Г. Конеллі, С. Джексон (C. Cameron, G. Connelly, S. Jackson) розглядають новий підхід - навчання та виховання у школі. Вони демонструють, що освіта та виховання повинні розглядатися як невід'ємні елементи як у сім'ї, так і в школі. У посібнику містяться приклади практичних занять, а також альтернативи виховної роботи для середньої та вищої школи. Він 
висвітлює потенційні переваги цілого ряду навчальних можливостей, ключових моментів виховання, тематичних досліджень, практичних завдань та корисних ресурсів (Cameron et al., 2015).

У Великій Британії зростає консенсус щодо самоконтролю, справедливості, вдячності й поваги, що сприяють моральному вихованню особистості, формують внутрішній характер, $€$ частиною вирішення багатьох викликів, що стоять сьогодні перед суспільством. Зокрема, у науковому звіті «Моральне виховання в школах Великої Британії» зазначено, що діти та дорослі живуть і вчаться краще з хорошим моральним характером, і що моральна цілісність також може позитивно впливати на результати діяльності в школах (Character education in UK schools, 2015).

Науковці М. Сенгер та Р. Огустроп (M. Sanger and R. Ogusthrope) зазначають, щоб діти стали здібними громадянами країни, їх потрібно забезпечити можливостями засвоєння моральних цінностей. Метою доробків науковців $\epsilon$ дослідження морального виховання дитини, приділяючи гостру увагу розподілу відповідальності. Наголошують, що не лише вчителі в школах можуть надавати дітям моральне виховання, але й батьки також відіграють важливу роль у тому, щоб діти усвідомлювали важливість моральних цінностей у своєму житті (Sanger \& Ogusthrope, 2013).

Проблеми морального виховання у британських школах досліджував також у своїх працях М. Волкер (M. Walker). Він виділив ключові принципи ефективності морального виховання в школах та дослідив вплив різних підходів у галузі морального виховання (Walker, 2017).

Варта дослідницької уваги наукова праця М. Тейлор (M. Taylor) «Цінності виховання в початковій та середній школі», де проаналізовано моральні, духовні, демократичні та екологічні цінності особистості. Наголошено, що школа має величезний вплив на виховання молоді. Описано різні погляди освітян на виховані цінності в межах сучасної освіти (Taylor, 1998).

У науковому дискурсі К. Картер (С. Carter) актуалізовані питання сімейного виховання дитини, повсякденні проблеми батьківства, висвітлено поради, як будувати здорові дружні стосунки один із одним та розвивати емоційний інтелект. Розкрито проблеми взаємодії з дітьми, розвиваючи в них ґрунтовні навички та мислення, які стануть основою для позитивних емоцій у подальшому розвитку дитини (Carter, 2011).

У розвідці «Виховання глобальних дітей» науковці С. Маршал та С. Бердан (S. Marshall, S. Berdan) пропонують обґрунтування та конкретні шляхи, які молодь може зробити, щоб відкрити для себе знання про цінності виховання. У праці міститься практична інформація, сотні порад та десятки 
історій із реального життя. Автори обґрунтовують важливість як малого, так і великого способу впливу дорослих на формування загальносвітового мислення в дітей, зокрема: допитливості, співпереживання, гнучкості та незалежності; вивчення культури за допомогою книг, їжі, музики та друзів; розширення світу дитини шляхом подорожей; допомога підліткам розвинути свою глобальну свідомість тощо (Marshall \& Berdan, 2013).

Д. Геррет та X. Піпер (D. Garratt \& H. Piper) у науковій публікації «Громадянське виховання в Англії та Уельсі: теоретична критика та практичні міркування» ілюструють теоретичну критику громадянського виховання в Англії та Уельсі як засобу підняття педагогічних міркувань для вчителів та питань політики для розробників навчальних програм шкіл. Спираючись на низку останніх емпіричних досліджень, вони аналізують практику і припускають, що відмінності між домінувальними моделями громадянства в Англії та Уельсі багато в чому пов'язані з їх історією (Garratt \& Piper, 2005).

Т. Расел, А. Беррі (T. Russell, А. Berry) (2014) у науковій публікації «Самостійне вивчення методики викладання та виховання вчителів у різних контекстах» висвітлюють методологію самонавчання, неформальну освіту, нетрадиційні шляхи до становлення педагога-вихователя. Запропоновані для опанування теми охоплюють основні концепції, особливості навчальновиховного середовища, навчальну практику, способи вдосконалення виховної роботи вчителів шкіл (Russell \& Berry, 2014).

У свою чергу, науковці C. Блендфорд та K. Ноулз (S. Blandford, C. Knowles) установили чіткі межі для побудови високоякісного викладання та навчання на основі чотирьох основних виховних цінностей, які, на їхню думку, є важливими для успіху підвищення рівня досягнення вчителів. У працях містяться навчальні поради для вчителів щодо вдосконалення виховних цінностей у дітей та молоді (Blandford \& Knowles, 2018).

Цікавою $є$ думка британського педагога-радниці 3 питань освіти Британської гуманістичної асоціації М. Мейсон (M. Mason), яка наголошує, що культурний і творчий розвиток індивіда впливає на формування почуття ії самобутності та цінностей, установлюючи стосунки особистості зі світом, що, у свою чергу, сприяє доведеним соціально-економічним гараздам суспільства. На її думку, Національний навчальний план головним чином зобов'язаний бути націлений на розвиток особистості учня за допомогою передачі знання та розуміння духовного, естетичного, морального, соціального та культурного різноманіття британського суспільства з урахуванням місцевого, національного, європейського та глобалізаційного вимірів сучасного життя. На її переконання, саме це і стимулює учнів до оцінки людських якостей і 
успіхів в естетичній, науковій, технологічній і соціальній сферах та допомагає їхньому активному залученню до виховної діяльності (M ason, 2000).

Висновки та перспективи подальших наукових розвідок. Аналіз праць у контексті дослідження показав, що британські дослідники все частіше акцентують увагу на тому, що для звершення високих виховних цінностей учнів потрібно не лише вдосконалювати загальну систему освіти країни, а й проводити повну реорганізацію шкіл, зокрема залучати до системи виховання не тільки вчителів і батьків, а й адміністрацію школи, громадськість, спільні зусилля, які могли би стати гарантією успішного виховного процесу. Це пояснюється тим, що британські педагоги вивчають виховний процес у закладах освіти, що здійснюється в межах культурних традицій, а власне процес навчання $€$ нескінченним кроком культурної реінкарнації, відкритою взаємодією між людьми. Отже, британські дослідники пізнають різні аспекти виховної роботи вчителів.

Нині зростає роль досліджень, які зорієнтовані на вивчення виховної роботи з огляду на світовий контекст. Доцільно зміщувати акценти в аналізі виховних систем освіти європейських країн, розширюючи спектр студіювання від вузького національного виміру до більш цілісного, повного опису, залучаючи міжнародний освітній аспект. Ґрунтовний аналіз зарубіжного й вітчизняного наукового дискурсу, що присвячений проблемі організації виховної роботи в закладах середньої освіти Великої Британії та відображає порівняльно-педагогічні системи освіти, може слугувати основою для необхідних освітніх перетворень в Україні, які спрямовані на підвищення ефективності та якості освітнього процесу й освітньої діяльності.

\section{ЛІТЕРАТУРА}

Червонецький, В. В., Червонецька, С. С. (2010). Традиції і тенденції використання природи в моральному вихованні дітей молодшого шкільного віку в сім'ї у Великій Британії. Луганськ: Видавництво СНУ ім. В. Даля (Chervonetskyi, V. V., Chervonetska, S. S. (2010). Traditions and trends in the use of nature in the moral education of primary school children in the family in the UK. Luhansk: SNU Publishing House).

Теклюк, Г. П. (2013). Проблеми сімейного виховання дітей підліткового віку у Великій Британії (дис. ... канд. пед. наук: 13.00.07). Вінниця (Tekliuk, Н. Р. (2013). Problems of family upbringing of adolescent children in Great Britain (PhD thesis). Vinnytsia).

Лещенко, М. П. (1996). Технології підготовки вчителів до естетичного виховання за рубежем (на матеріалах Великобританії, Канади, США) (дис. ... д-ра пед. наук: 13.00.04). Київ (Leshchenko, М. Р. (1996). Technologies of teacher training for aesthetic education abroad (on the materials of Great Britain, Canada, USA) (DSc thesis). Kyiv).

Величко, Н. А. (2015). Естетичне виховання молодших школярів у загальноосвітній школі Великої Британії (дис. ... канд. пед. наук: 13.00.01). Дрогобич (Velychko, N. A. (2015). Aesthetic education of primary school children in secondary school in Great Britain (PhD thesis). Drohobych). 
Локшина, О. І. (2009). Зміст шкільної освіти в країнах Європейського Союзу: теорія і практика (друга половина XX - початок XXI cm.). К.: Богданова A.M. (Lokshyna, 0. I. (2009). The content of school education in the countries of the European Union: theory and practice (second half of the XX - beginning of the XXI century). K.: Bohdanova A. M.).

Мороз, Н. С. (2009). Система виховної роботи в середніх навчальних закладах Великої Британії (дис. ... канд. наук: 13.00.07). Дрогобич (M oroz, N. S. (2009). The system of educational work in secondary schools in Great Britain (PhD thesis). Drohobych).

Кравченко, Т. В. (2019). Особливості патріотичного виховання в Великобританії. Молодий вчений, 11 (75), 907-911 (Kravchenko, T. V. (2019). Features of patriotic education in the UK. Young scientist, 11 (75), 907-911).

Лушпай, Л. І. (2012). Гендерне виховання учнів середніх навчальних закладів у Великій Британії (автореф. дис. ... канд. пед. наук: 13.00.07). Тернопіль (Lushpai, L. I. (2012). Gender education of students in secondary schools in the UK (PhD thesis abstract). Ternopil).

Сбруєва, А. (2004). Тенденції реформування середньої освіти розвинених англомовних країн в контексті глобалізації (90-ті рр. XX - початок XXI cm.) (дис. ... д-ра пед. наук: 13.00.01). Київ (Sbruieva, А. (2004). Tendencies of reforming secondary education in developed English-speaking countries in the context of globalization (90s of the XX - beginning of the XXI century) (DSc thesis). Kyiv).

Wayne, E. (2013). How to Raise Children Successfully. London: Parenting.

Peterson Fenn, M. (2011). Bringing Up Brits: Expat Parents Raising Cross-Cultural Kids in Britain. London: Live It.

Connelly, G., Jackson, S. \& Cameron, C. (2015). Educating Children and Young People in Care: Learning Placements and Caring Schools. London: Jessica Kingsley Publishers.

Character education in UK schools. Research report (2015). Retrieved from: file:///C:/Users/\%D0\%A2\%D0\%B0\%D0\%BD\%D1\%8F/Downloads/Character Education i n UK Schoolsfinalreport.pdf.

Sanger, M. \& Ogusthrope, R. (2013). M odeling as M oral Education: Documenting, Analyzing, and Addressing a Central Belief of Preservice Teachers'. Teaching and Teacher Education, Vol. 29, 167-176.

Walker, M. (2017). Case Study Report - Leading Character Education in Schools. London: National Foundation for Educational Research.

Taylor, M. (1998). Values education in primary and secondary schools. Slough: NFER.

Carter, C. (2011). Raising Happiness: 10 Simple Steps for M ore Joyful Kids and Happier Parents. London: Ballantine Books.

Marshall, S., Berdan, S. (2013). Raising Global Children Paperback. Virginia: American Council on the Teaching of Foreign Languages.

Garratt, D. \& Piper, H. (2008). Citizenship education in England and Wales: theoretical critique and practical considerations. Teachers and Teaching theory and practice, Vol. 14, 481496.

Russell, T., \& Berry, A. (2014). Self-study of teaching and teacher education practices in diverse contexts. Studying Teacher Education, 10 (2), 101-102.

Blandford, S., Knowles, C. (2018). Bloomsbury CPD Library: Raising Attainment in the Primary Classroom. London: Bloomsbury Education.

Mason, M. (2000). Creativity, Culture and Humanist Spirituality. REC seminar. Retrieved from: http://www. humanism.org.uk./site/cms/contentviewarticle.asp?article=1263. 


\section{PEЗЮME}

Швыденко Валентина. Состояние обработки проблемы организации воспитательной работы в учреждениях среднего образования Великобритании в современном научном дискурсе.

В статье раскрыта проблема организации воспитательной работы в учреждениях среднего образования Великобритании в трудах отечественных и зарубежных ученых. Освещены различные взгляды педагогов на воспитание в учреждениях среднего образования Великобритании, основное внимание которых сосредоточено на воспитании нравственных качеств детей, организации семейного воспитания детей Великобритании. В статье показана роль современной британской семьи в воспитании детей, указано, что интегративной составляющей является ориентация на воспитание личности с развитым эстетическим мировоззрением, основанная на общечеловеческих ценностях и приоритетах. Отражено патриотическое воспитание, которое способствует критическому диалогу и демократическому процессу, способно объединить людей во всем многообразии многонационального общества. Продемонстрировано гендерное воспитание детей средних учебных заведений в Великобритании.

Ключевые слова: воспитательная работа, заведения среднего образования, Великобритания, дети, образование.

\section{SUMMARY}

Shydenko Valentyna. The state of working on the problem of organization educational work in the secondary education institution in the Great Britain in modern scientific discourse.

The article reveals the problem of organizing the educational work in secondary schools of Great Britain in the works of national and foreign scientists, different views of teachers on education in secondary schools in the UK, the main focus of which is on the upbringing of moral qualities of children, organization of family education in Great Britain. The article shows the role of the modern British family in the upbringing of children, notes that the integrative component is the focus on the upbringing of a person with a developed aesthetic worldview, which is based on the universal values and priorities. It reflects a patriotic education that promotes critical dialogue and the democratic process, capable of uniting people in all the diversity of a multinational society. The article demonstrates gender education of secondary school students in Great Britain.

Now the role of research is growing, that focuses on the study of educational work in the light of the global context. It is advisable to shift the emphasis in the analysis of educational systems of European countries, expanding the range of studies from a narrow national dimension to a more holistic, complete description, involving the international educational aspect. A thorough analysis of foreign and national scientific discourse on the organization of educational work in secondary education institutions in the UK and reflects the comparative pedagogical systems of education, can serve as a basis for the necessary educational transformations in Ukraine, aimed at improving the efficiency and quality of educational activities.

Key words educational work, secondary education institutions, Great Britain, children, education. 